\title{
Rising of Rape Cases in Globalised scenario: A Critical Study of Karnataka
}

\author{
Dr.R.N.Mangoli*, Dr.Nandini.G.Devarmani** \\ * Associate Professor, School of Criminology and Criminal Justice, Rani Channamma \\ University, Belagavi-591156. \\ ** Assistant Professor, School of Criminology and Criminal Justice, Rani Channamma \\ University, Belagavi-591156.
}

\begin{abstract}
The rape incident echoed in the assembly over the rape case of 6 year old student in Bangalore's private school recently on July 2, 2014. Blame game, instead taking collective responsibility by each elected member they just try to blame each other by the so called elected representatives. Moreover, police have invoked Section 376 (rape) of IPC and Sections 4 and 6 of Prevention of Child Sexual Abuse (POCSO) Act 2012. Forget about the rape cases occurred at the remote places, today rapes have become very common in the school premises in a day light. Children are being easily targeted and victimizing, is it the effect of globalizing. In Karnataka over 1000 rapes have been reported in 2013 as per the State Crime Record Bureau. It means on an average around two rape cases have been registered in each day in 2013. The other pathetic condition in the state is that the rate of conviction in Karnataka was 11.6 per cent in 2010, dropping to 9.3 per cent in 2011. In 2012, just 434 of the 23,525 charge-sheeted, went to jail, forming 6.5 per cent (TOI Arun 30 Jan 2014).

In order to safe guard the school going children the Police have now been implemented the New Strict Guidelines to be implemented within 31 of Aug 2014. However, it is now questionable, whether the rising rape cases in Karnataka State will be contained by these guidelines apart from the recent new laws have been enacted and made amendments in the Criminal Law by enhancing punishments for rapist after Nirabhaya Case. The present study is therefore intended to examine whether the women and children in our society are safe from the unwanted sexual violence.
\end{abstract}

Key Words: Rising Rapes, Child Sexual Abuse, Sexual Violence, Law of the Land and Police.

\section{Introduction}

The state reported 1,061 cases of rapes in 2013 the maximum in the last three years. This includes 563 cases of rape on minors. However, only 26 persons were convicted of rape last year. And the number of rape accused convicted in the first half of this year is zero (Coastal Digest 4 July 2014). Similarly, an emerging trend in the incidence of rape has been observed during the period 2009-2013 at the National Level against both women and children. As per the Crime in India Report 2013, the total 33707 rape cases of women have been registered in 2013 where as 12363 rape cases of children have been registered. These are just registered cases, there are huge number of rape crimes which have not been reported and registered. If we take only the registered rape cases, it will be really a pathetic condition of lawlessness in the society.is it due to globalisation, Does it really improve and impact on the situation by change of Baton from one Police Commissioner to another Police Commissioner as it has happened by changing the Bangalore City Police Chief Raghavendra Auradhkar to M.N.Reddy. The present critical study is based on the huge data available in the news papers and media reported many cases of rapes in recent past.

\section{Objectives of the Study}

- To study the incidents of rape cases in Karnataka.

- To critically analyse the rate of rape cases in Karnataka.

- To understand the steps taken in prevention and control the rape incidents.

\section{Incidents of Rape Cases in Karnataka}

The state reported 1,061 cases of rapes in 2013 the maximum in the last three years. This includes 563 cases of rape on minors. However, only 26 persons were convicted of rape last year. And the number of rape accused convicted in the first half of this year is zero (Coastal Digest 4 July 2014).

The information was provided by home minister KJ George while replying to C Motamma (Congress) in the legislative council on Thursday. The first half of 2014 has already reported 476 cases of rapes, including 325 cases of rape on minors. Admitting that the acquittal rate was high, George said the government was planning to set up a board to train public prosecutors to fight the cases better (Coastal Digest 4 July 2014). 
Table-I Strength of IPS Officers in India

\begin{tabular}{|c|c|c|c|c|c|}
\hline \multicolumn{3}{|c|}{$\begin{array}{l}\text { DECLINING STRENGTH } \\
\text { At the senior level, } 1,093 \text { IPS posts } \\
\text { have been lying vacant }\end{array}$} & \multicolumn{3}{|c|}{ 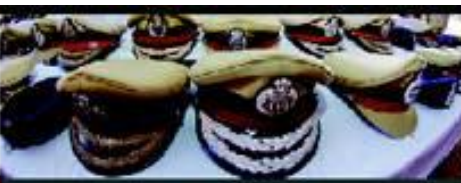 } \\
\hline \multicolumn{3}{|c|}{ IPS VACANCIES } & \multicolumn{3}{|c|}{ POLICE-POPULATION RATIO } \\
\hline STATES & $\begin{array}{l}\text { SANCTIONED } \\
\text { STRENGTH }\end{array}$ & VACANCIES & | STATES & SAMCTIONED & ACTUAL \\
\hline Nagaland & 70 & 35 & Bihar & 69.76 & 54.73 \\
\hline Odisha & 188 & 84 & W Bengal & 100.58 & 61.59 \\
\hline Kerala & 163 & 57 & UP & 160.93 & 67.76 \\
\hline Karnataka & 205 & 70 & Odisha & 81.05 & 71.24 \\
\hline Maharashtra & 302 & 101 & MP & 90.97 & 75.19 \\
\hline All India & 4,730 & 1,093 & All India & 145.02 & 106.79 \\
\hline
\end{tabular}

"Figures as on January 1,2013 UN Recommended Ratio: 222

Sources: Times of India dated 22 July 2014.

At a time when people feel increasingly unsafe on the streets and spectre of terror attacks keeps security agencies on the toes, India stares at an abysmal police population ratio of 106 policemen per one lakh people less than half of the UN recommended figure of 222. Even at the senior level, 1093 IPS posts are lying vacant, according to the latest government data (TOI 22 July 2014).

Shortage of Policemen is also one of the major problem. It is clear from Table-I that how at the senior level IPS officers posts have been lying vacant. In Karnataka out 205 sanctioned strength only 70 vacancies have been filled up. And off course this must be the one of the set back in the state.

\section{Analysis of the Rate of Rape Cases}

Karnataka reported around two rape cases a day in 2013, almost double the number logged over the past three years. Clearly, this shows sexual violence has not abated in the state, despite stepped-up police security in the aftermath of the Nirbhaya gang rape (TOI Manu 5 Aug 2013)

VS Ugrappa (Congress) said the maximum time allowed to file charge sheet after registration of cases should be reduced to 30 days from the current 90 , to make the case stronger and reduce the acquittal rate in rape cases (Coastal Digest 4 July 2014).

As per the Crime in India Report 2013, among the 53 Mega Cities, Bangalore stood third in Crime against women in India. Incidents of Rape are equally increasing in both women and children continuously from past several years. This can be viewed by the following tables.

Table-II Incident of Rape u/s 376 of IPC

\begin{tabular}{|l|l|l|l|l|l|l|l|}
\hline SI No & Crime & 2009 & 2010 & 2011 & 2012 & 2013 & $\begin{array}{l}\% \text { Variation in } \\
2013 \text { over 2012 }\end{array}$ \\
\hline 1 & $\begin{array}{l}\text { Rape } \\
\text { (Sec 376 IPC) }\end{array}$ & 21397 & 22172 & 24206 & 24923 & 33707 & 35.2 \\
\hline
\end{tabular}

Sources: Crime in India 2013, Govt of India.

An emerging trend in the incidence of rape has been observed during the period 2009-2013. These cases have reported an increase of 3.6\% in 2010 over 2009 and an increase of $9.2 \%$ in the year 2011 over the year 2010, an increase of 3.0\% in the year 2012 over 2011 and further an increase of 35.2\% in the year 2013 over 2012.

It is a serious matter to observe an increase of $35.2 \%$ in the year 2013 over 2012 the rate of rape incidents, which clearly indicates the pathetic condition of law and order in the country.

Table-III Incident of rape u/s 376 of IPC (Children)

\begin{tabular}{|l|l|l|l|l|l|}
\hline SI No & Crime & 2011 & 2012 & 2013 & $\begin{array}{l}\text { \% Variation in } \\
2013 \text { over 2012 }\end{array}$ \\
\hline 1 & $\begin{array}{l}\text { Rape } \\
\text { (Sec 376 IPC) }\end{array}$ & 7112 & 8541 & 12363 & 44.7 \\
\hline
\end{tabular}

Sources: Crime in India 2013, Govt of India. 
Similarly, a total of 12363 cases of child rape were reported in the country during 2013 as compared to 8541 in 2012 accounting for an increase of $44.7 \%$ during the year 2013. By observing both the tables it is crystal clear that the women and children in the country are not safe even after the stringent laws have been enacted after the Nirabhaya case as well as POCSO Act 2012.

There were 33,764 victims of rape out of 33,707 reported rape cases in the country during the year 2013. $13.1 \%(4,427$ out of 33,764$)$ of the total victims of rape were girls under 14 years of age, while $26.3 \%$ ( 8,877 victims out of 33,764$)$ were teen-aged girls (14-18 years). $46.1 \%$ (15,556 victims) were women in the age-group 18-30 years. However, $13.8 \%$ (4,648 victims) victims were in the age-group of 30-50 years while $0.7 \%$ (256 victims) was over 50 years of age (Crime in India 2013).

\section{Steps Taken for Controlling the Rape Cases}

Hon'able Chief Minister Siddaramaiah announced that an expert committee comprising legal luminaries would be constituted to suggest preventive measures to be taken to avoid rapes. He said the panel would also be asked to suggest ways and means for speedy disposal of rape cases and stringent penal clauses. He said the state government has already issued an order to set up 10 fast-track courts to try cases of crimes against women. "The move is awaiting High Court's nod," (Coastal Digest 4 July 2014).

The legislature committee on women and child welfare, which looked into issues such as increasing incidents of rape, atrocity, domestic violence, child marriage and exhibition of obscene films, had last year recommended that those committing crimes against women be booked under the Goonda Act and issued nonbailable warrant (Coastal Digest 4 July 2014).

"There were several instances where mobile phones were used to lure girls to remote places and rape them. Mobile phones are debasing the educational atmosphere in schools and colleges," said a report tabled by the women and child welfare Committee chairperson Puttur MLA Shakuntala Shetty. In the legislative assembly here on Friday 11 July 2014. The report went on to recommend a ban on mobiles (TOI 12 July 20014).

The National Human Rights Commission (NHRC) Tuesday asked the Karnataka government to send a report on the alleged rape of a six-year-old in a private school in Bangalore. "The commission has issued notice to the chief secretary, director general of police and district collector calling for a report within two weeks," NHRC said in a statement (Firstpost.com 23 July 2014)

Karnataka Government is not only taking stringent action by implementing new kind of guidelines but also immediately changed the Bangalore city police chief as an effective measure against the crime against women and children.

In the wake of the rape of a six-year-old girl in a private school, the City Police has issued 11-point guidelines to be implemented by all schools by the end of August 2014. The guidelines have been issued under the Karnataka Police Act, 1963, and schools that do not implement them will be prosecuted under section 188 of the Indian Penal Code (negligence leading to injury or death of a person), said M.N. Reedi, City Police Commissioner.

The private school where the six-year-old was raped by the skating instructor has been given time till August 14 to implement all the guidelines.

\section{Some of the important guideline are:}

- Schools have to compulsorily install GPS and CCTV in all school buses and CCTV in school premises

- Schools authorities must appoint Floor Vigilance Officer

- After dropping the children to school, the bus drivers and attendants must be isolated from the children

- Only authorised persons should be allowed inside the school premises

- Schools must issue identity cards to parents, who pick up and drop their wards to school

- In case parents with identity cards cannot come to pick up their wards, they must compulsorily inform the school teacher concerned through SMS, besides authorising someone else to pick up their child (The Hindu 27 July 2014).

\section{Conclusion}

It is stunning to reveal that in most of the rape cases occurred during 2013, offenders were know to victims as many as in $94.4 \%$ of rape cases ( 31807 out of 33707 cases). Under the circumstances the close watch as a measure to prevent such incidents of rapes be put on the people known to the women and children. Particularly, parents have to play a major role before handing over to their children to their near relatives, friends, teachers, made, drivers and watchmen etc. More than Police, parents need to have a close watch on these peoples who come into contact in their day to day activities.

If the situation is not controlled, the day is not far that the next step after huge protest against the rising rapes in the society, people surely take law in their hand. This is the clear indication of lawlessness and a situation of anomie prevails. Therefore, it is very important to maintain law and order in the society by way of 
speedy trial and stringent punishments not just by the mere word Globalisation but implementation in action is what is needed by the hour.

\section{References}

[1]. Arun Dev (2014) http://timesofindia.indiatimes.com/city/bangalore/Crime-against-women-Karnataka-sees-90-accused-walkfree/articleshow/29613439.cms retrieved dated 27-7-2014.

[2]. Deeptiman.Tiwary (2014) http://timesofindia.indiatimes.com/india/Only-106-cops-per-1-lakh-Indians/articleshow/30869512.cms retrieved dated 28-7-2014

[3]. Manu Aiyappa (2013) http://timesofindia.indiatimes.com/india/Rise-in-rape-cases-rattles-Karnatakagovt/articleshow/21613542.cms retrieved dated 27-7-2014

[4]. Agustín Fuentes (2014) http://www.psychologytoday.com/blog/busting-myths-about-human-nature/201407/the-real-reason-sexualviolence-is-so-widespread retrieved on $28 / 7 / 2014$

[5]. http://www.firstpost.com/fwire/bangalore-rape-case-nhrcs-notice-to-karnataka-1629967.html retrieved on 28/7/2014

[6]. http://www.thehindu.com/news/national/bangalore-police-issue-guidelines-for-schools/article6252787.ece retrieved on 28/7/2014.

[7]. http://www.coastaldigest.com/index.php/news/66127-over-1000-rapes-reported-in-karnataka-in-2013 retrieved dated 27-7-2014 